\title{
Conventional and novel stem cell based therapies for androgenic alopecia
}

\author{
This article was published in the following Dove Press journal: \\ Stem Cells and Cloning:Advances and Applications \\ 3I August 2017 \\ Number of times this article has been viewed
}

\section{Dodanim Talavera-Adame' Daniella Newman ${ }^{2}$ Nathan Newman'}

'American Advanced Medical Corp. (Private Practice), Beverly Hills, CA, ${ }^{2}$ Western University of Health Sciences, Pomona, CA, USA

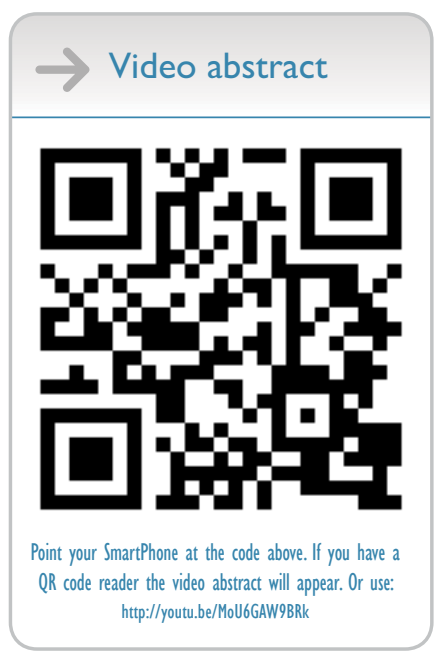

Correspondence: Nathan Newman 930I Wilshire Blvd, Suite 303, Beverly Hills, CA 90210, USA

Tel +I 3102733344

Fax+l 310273765I

Email Doctor@nathannewmanmd.com
Abstract: The prevalence of androgenic alopecia (AGA) increases with age and it affects both men and women. Patients diagnosed with AGA may experience decreased quality of life, depression, and feel self-conscious. There are a variety of therapeutic options ranging from prescription drugs to non-prescription medications. Currently, AGA involves an annual global market revenue of US $\$ 4$ billion and a growth rate of $1.8 \%$, indicating a growing consumer market. Although natural and synthetic ingredients can promote hair growth and, therefore, be useful to treat AGA, some of them have important adverse effects and unknown mechanisms of action that limit their use and benefits. Biologic factors that include signaling from stem cells, dermal papilla cells, and platelet-rich plasma are some of the current therapeutic agents being studied for hair restoration with milder side effects. However, most of the mechanisms exerted by these factors in hair restoration are still being researched. In this review, we analyze the therapeutic agents that have been used for AGA and emphasize the potential of new therapies based on advances in stem cell technologies and regenerative medicine.

Keywords: stem cells, stem cell therapies, hair follicle, dermal papilla, androgenic alopecia, laser, hair regeneration

\section{Introduction}

The prevalence of androgenic alopecia (AGA) increases with age, and is estimated to affect about $80 \%$ of Caucasian men. ${ }^{1}$ Female AGA, also known as female pattern hair loss, affects $32 \%$ of women in the ninth decade of life. ${ }^{2}$ The consumer market for products that promote hair growth has been increasing dramatically. ${ }^{3}$ These products promote hair regeneration based on the knowledge about the hair follicle (HF) cycle., ${ }^{4,5}$ However, in most cases, the mechanisms of action of these products are not well characterized and the results are variable or with undesirable side effects. ${ }^{6}$ At present, only two treatments for AGA have been approved by the US Food and Drug Administration (FDA): Minoxidil and Finasteride. ${ }^{7-10}$ Although these medications have proved to be effective in some cases, their use is limited by their side effects. ${ }^{11,12}$ With the emergence of stem cells (SCs), many mechanisms that lead to tissue regeneration have been discovered. ${ }^{13}$ Hair regeneration has become one of the targets for SC technologies to restore the hair in AGA. ${ }^{14}$ Several SC factors such as peptides exert essential signals to promote hair regrowth. ${ }^{15,16}$ Some of these signals stimulate differentiation of SCs to keratinocytes which are important for HF growth. ${ }^{17}$ Other signals can stimulate dermal papilla cells (DPCs) that promote SC proliferation in the HF. ${ }^{18,19}$ In this review, we describe HF characteristics and discuss different therapies used currently for AGA and possible novel agents for hair regeneration. These therapies include FDA-approved

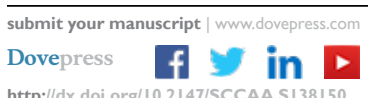


medications, non-prescription physical or chemical agents, natural ingredients, small molecules, biologic factors, and signals derived from SCs.

\section{$\mathrm{HF}$ and SC niche}

The HF undergoes biologic changes from an actively growing stage (anagen) to a quiescent stage (telogen) with an intermediate remodeling stage (catagen). ${ }^{4}$ HFSCs are located in the bulge region of the follicle and they interact with mesenchymal SCs (MSCs) located in the dermal papilla (DP). ${ }^{18}$ These signal exchanges promote activation of some cellular pathways that are essential for DPC growth, function, and survival, such as the activation of Wnt signaling pathway. ${ }^{19-21}$ Other signals, such as those from endothelial cells (ECs) located at the DP, are also essential for HF maintenance. ${ }^{22} \mathrm{EC}$ dysfunction that impairs adequate blood supply may limits or inhibits hair growth. ${ }^{22}$ For instance, Minoxidil, a synthetic agent, is able to promote hair growth by increasing blood flow and the production of prostaglandin E2 (PGE2). ${ }^{7}$ It has been shown that proteins that belong to the transforming growth factor (TGF) superfamily, such as bone morphogenetic proteins (BMPs), also exert signals to maintain the capacity of DPCs to induce HF growing in vivo and in vitro. ${ }^{23}$ These BMPs may be released by several cells that compose the follicle, including ECs. ${ }^{24-26}$ ECs may provide signals for
BMP receptor activation in DPCs similar to those signals that promote survival of MSCs in human embryoid bodies composed of multipotent cells. ${ }^{24,25}$ DPCs have been derived from pluripotent SCs in an attempt to study their potential for hair regeneration in vitro and in vivo. ${ }^{27}$ Together, dermal blood vessels and DPCs orchestrate a suitable microenvironment for the growth and survival of HFSCs. ${ }^{28,29}$ Interestingly, the expression of Forkhead box $\mathrm{C} 1$ regulates the quiescence of HFSCs located in the bulge region (Figure 1). ${ }^{30}$ HFSCs are quiescent during mid-anagen and maintain this stage until the next hair cycle. ${ }^{29,30}$ However, during early anagen stage, these cells undergo a short proliferative phase in which they self-renew and produce new hair. ${ }^{30}$ Therefore, the bulge region constitutes a $\mathrm{SC}$ niche that makes multiple signals toward quiescence or proliferation stages. ${ }^{30-34}$ It is known that fibroblasts and adipocyte signals are able to inhibit the proliferation of HFSCs. ${ }^{34}$ Additionally, BMP6 and fibroblast growth factor 18 (FGF18) from bulge cells exert inhibitory effects on HFSC proliferation. ${ }^{34}$ Dihydrotestosterone (DHT) also inhibits HF growth. ${ }^{35}$ Agents that reduce DHT, such as Finasteride, promote hair regrowth by inhibiting Type II $5 \alpha$-reductase. ${ }^{8,14,36}$ In contrast to these inhibitory effects, DPCs located at the base of the HF provide activation signals (Figure 1). ${ }^{18,34}$ The crosstalk between DPCs and HFSCs leads to inhibition of inhibitory effects with the resultant cell

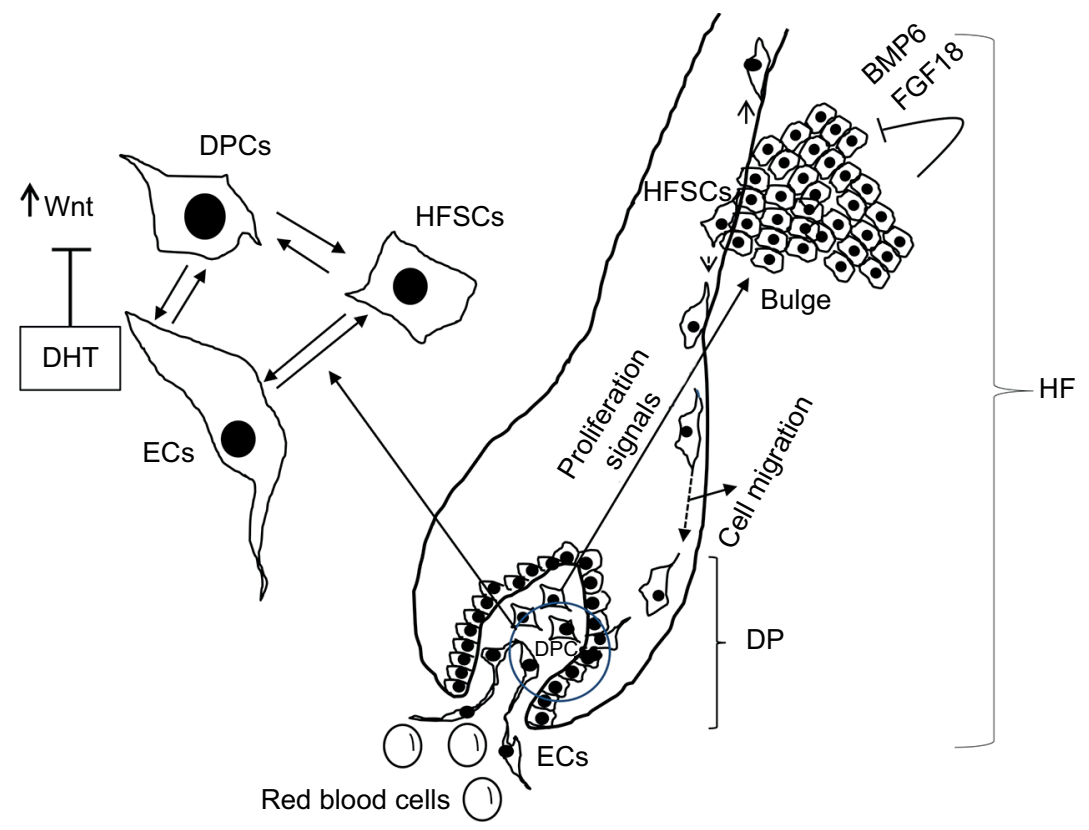

Figure I Diagram of the HF and factors involved in hair regeneration.

Notes: The HF is composed of different cell types including HFSCs, DPCs, and ECs, among others. HFSCs migrate from the bulge area after activation by growth factors released by DPCs. However, BMP6 and FGFI8 from the bulge cells exert autocrine inhibitory effects in HFSC proliferation. Once the HFSCs are closer to DPCs and ECs, they differentiate and proliferate during anagen phase, forming new hair. Activation of Wnt signaling is essential for DPCs to release the factors that promote differentiation and proliferation of HFSCs. DHT interferes with this Wnt signaling and, in this way, inhibits hair growth and promotes hair miniaturization. Effective cell-cell interactions between HFSCs, DPCs, and ECs are essential for hair growth.

Abbreviations: BMP6, bone morphogenetic protein 6; DHT, dihydrotestosterone; DP, dermal papilla; DPCs, dermal papilla cells; ECs, endothelial cells; FGFI8, fibroblast growth factor 18; HF, hair follicle; HFSCs, hair follicle stem cells. 
proliferation toward hair regeneration (anagen). ${ }^{30,31,37}$ With the self-renewal of HFSCs, the outer root sheath (ORS) forms, and signals from DPCs to the bulge cells diminish in a way that the bulge cells start again with their quiescent stage ${ }^{4,34}$ As mentioned earlier, Forkhead box $\mathrm{C} 1$ transcription factor has an important role in maintaining the threshold for HFSC activation. ${ }^{30}$ The knockdown of these factors in bulge cells reduces the cells' threshold for proliferation, and the anagen cycle starts more frequently due to promotion of HFSC proliferation in shorter periods of time. ${ }^{30}$

\section{Prescribed and non-prescription products that promote hair growth and possible mechanisms of action \\ FDA-approved chemical agents}

At present, the only therapeutic agents for AGA approved by the FDA in the USA are Finasteride and Minoxidil. ${ }^{9,10}$ Minoxidil promotes hair growth by increasing the blood flow and by PGE2 production. ${ }^{7}$ Although Minoxidil is now a non-prescription medication, Finasteride and other drugs require a medical prescription for AGA treatment (Table 1). Dutasteride and Finasteride inhibit $5 \alpha$-reductase, blocking the conversion of testosterone to DHT. ${ }^{36,38}$ While Finasteride is a selective inhibitor of type II $5 \alpha$-reductase, Dutasteride inhibits type I and type II $5 \alpha$-reductases. These medications have also been used to treat benign prostatic hyperplasia. ${ }^{39}$

\section{Natural ingredients}

In addition to prescribed medications, some natural ingredients have been used to promote hair growth (Table 2). For example, procyanidin B-2 (found in apples and in several plants) is able to inhibit the translocation of protein kinase $\mathrm{C}$ (PKC) in hair epithelial cells. ${ }^{40} \mathrm{PKC}$ isozymes, such as PKC- $\beta$ I and - $\beta$ II, play an important role in hair cycle progression and inhibiting their translocation can promote hair growth. ${ }^{40}$ Procyanidin B-3 can promote hair growth by inhibiting TGF- $\beta 1 .^{41}$ Another group of natural ingredients, such as saw palmetto, alfatradiol, and green tea (Epigallocatechin gallate), have the capacity to inhibit $5 \alpha$-reductase and block DHT production. ${ }^{42-44}$ The natural ingredients and their proposed mechanisms of action are summarized in Table 2 (the commercial web page is included, since there are no formal studies about their mechanisms of action).

\section{Laser therapy}

Light amplification by stimulated emission of radiation (LASER) generates electromagnetic radiation which is uniform in polarization, phase, and wavelength. ${ }^{45}$ Lowlevel laser therapy (LLLT), also called "cold laser" therapy, since it utilizes lower power densities than those needed to produce heating of tissue. Transdermal LLLT has been used for therapeutic purposes via photobiomodulation. ${ }^{46,47}$ Several clinical conditions, such as rheumatoid arthritis, mucositis, pain, and other inflammatory diseases, have been treated with these laser devices. ${ }^{48-50}$ LLLT promotes cell proliferation by stimulating cellular production of adenosine triphosphate and creating a shift in overall cell redox potential toward greater intracellular oxidation. ${ }^{51}$ The redox state of the cell regulates activation of signaling pathways that ultimately promotes high transcription factor activity and gene expression of factors associated with the cell cycle. ${ }^{52}$ Physical agents such as lasers have been also used to prevent hair loss in a wavelength range in the red and near infrared (600-1,070 nm). ${ }^{5,47,51,53}$ Laser therapy emits light that penetrates the scalp and promotes hair growth by increasing the blood flow. ${ }^{54}$ This increase gives rise to EC proliferation and migration due to upregulation of vascular endothelial growth factor (VEGF) and endothelial nitric oxide synthase. ${ }^{55,56}$ In addition, the laser energy itself stimulates metabolism in catagen or telogen follicles, resulting in the production of anagen hair. ${ }^{53,54} \mathrm{~A}$ specific effect of LLLT has been demonstrated to promote proliferation of HFSCs, forcing the hair to start the anagen phase. ${ }^{57}$

\section{Biologic agents that promote hair growth and their mechanisms of action SC signaling}

Recently, it has been found that SCs release factors that can promote hair growth. ${ }^{16}$ These factors and their mechanisms of action have been summarized in Table 3. These factors, known as "secretomes", are able to promote skin regeneration, wound healing, and immunologic modulation, among other effects. ${ }^{58,59}$

Table I Prescribed products used for AGA

\begin{tabular}{lll}
\hline Prescribed products & Source & Mechanism of action \\
\hline Finasteride/Dutasteride 9,10 & Synthetic (small molecule) & Inhibits type II, 5 $\alpha$-reductase \\
Latanoprost and Bimatoprost ${ }^{36,38,39,79,80}$ & $\begin{array}{l}\text { Synthetic prostaglandin analog of PGF2 } \alpha \text { (originally used } \\
\text { to decrease ocular pressure in glaucoma) }\end{array}$ & Activates prostaglandin receptor \\
\hline
\end{tabular}

Abbreviation: AGA, androgenic alopecia; PGF $2 \alpha$, prostaglandin F2 $\alpha$. 
Table 2 Non-prescription products used for AGA and their proposed mechanisms of action

\begin{tabular}{|c|c|c|}
\hline Non-prescription product & Source & Proposed mechanism of action \\
\hline Minoxidyl (FDA approved) ${ }^{9}$ & Synthetic (small molecule) & $\begin{array}{l}\text { Potassium channel opener and powerful } \\
\text { vasodilator used in hypertension }\end{array}$ \\
\hline Apple Procyanidin B-2 (extract from apples) ${ }^{40}$ & Natural (apples and several plants) & $\begin{array}{l}\text { Inhibitor of translocation of PKC isozymes in hair } \\
\text { epithelial cells }\end{array}$ \\
\hline $\begin{array}{l}\text { Procerin (saw palmetto extract and other ingredients } \\
\text { such as iodine, gotu kola, magnesium, grape seed } \\
\text { extract, biotin, niacin, and vitamin } \mathrm{B} / 2)^{42}\end{array}$ & $\begin{array}{l}\text { Natural (small plant named saw } \\
\text { palmetto) }\end{array}$ & $\begin{array}{l}\text { Used to treat benign prostatic hyperplasia. } \\
\text { Inhibits type I and II } 5 \alpha \text {-reductase and blocks } \\
\text { DHT production }\end{array}$ \\
\hline Provillus (www.provillus.com) & $\begin{array}{l}\text { Formulation (Minoxidil } 2 \text { or } 5 \% \text {, biotin, } \\
\mathrm{Zn}, \mathrm{Fe}, \mathrm{Mg}, \mathrm{Ca}, \mathrm{B} 6 \text { complex) }\end{array}$ & $\begin{array}{l}\text { Contains Minoxidil and more vitamins (similar } \\
\text { ingredients to Procerin) }\end{array}$ \\
\hline $\begin{array}{l}\text { Follicusan (https://www.ulpros pector.com/en/na/P } \\
\text { ersonalCare/Detail//38I/216299/Follic usan-DP) }\end{array}$ & $\begin{array}{l}\text { Natural (milk-based bioactive } \\
\text { compound) }\end{array}$ & $\begin{array}{l}\text { Stimulates cellular functioning in the scalp and } \\
\text { hair follicle. Stimulates dermal papilla cells. } \\
\text { Improve hair density and thickness }\end{array}$ \\
\hline $\begin{array}{l}\text { Musol } 20 \text { (http://www.cosmet icingredients.co.uk/ } \\
\text { Ingredient/musol-20-pf) }\end{array}$ & Natural (yeast extract, mucoprotein) & $\begin{array}{l}\text { Physically deposited as a protective covering to } \\
\text { create thicker hair }\end{array}$ \\
\hline $\begin{array}{l}\text { Capixyl (http://lucasmeyerc osmetics.com/en/products/ } \\
\text { product.php? id=6) }\end{array}$ & $\begin{array}{l}\text { Synthetic and natural (four amino } \\
\text { acids biomimetic peptide with red } \\
\text { clover extract; rich in biochanin A } \\
\text { [antioxidant]) }\end{array}$ & $\begin{array}{l}\text { Inhibitor of } 5 \alpha \text {-reductase, improves ECM } \\
\text { proteins; it reduces inflammation }\end{array}$ \\
\hline $\begin{array}{l}\text { EMortal Pep (http://www.revagain.co.kr/goods/ } \\
\text { catalog?code }=0002 \text { ) }\end{array}$ & Synthetic and natural & $\begin{array}{l}\text { Blocks upregulation of TGF- } \beta \text { I induced by DHT. } \\
\text { Activates dermal papilla cells }\end{array}$ \\
\hline $\begin{array}{l}\text { Planoxia-RG (https://www.ulpros pector.com/en/na/ } \\
\text { PersonalCare/Detail/53|4//95870/PLAN OXIA-RG) }\end{array}$ & Natural & $\begin{array}{l}\text { Promotes transition from telogen phase to } \\
\text { anagen phase }\end{array}$ \\
\hline $\begin{array}{l}\text { Tricholastyl (http://dir.cosmetics andtoiletries.com/ } \\
\text { detail/tradeName.html ?id=17820) }\end{array}$ & $\begin{array}{l}\text { Natural (water, mannitol, Pterocarpus } \\
\text { marsupium bark extract, disodium } \\
\text { succinate, glutamic acid) }\end{array}$ & $\begin{array}{l}\text { Antiglycation activity. In this way, it restores the } \\
\text { hair growth cycle }\end{array}$ \\
\hline $\begin{array}{l}\text { Keramino-25 (http://www.lonza.c om/ } \\
\text { productsservices/consumercare/personalcare/proteins/ } \\
\text { animal-proteins/keramino-25.aspx) }\end{array}$ & Synthetic & $\begin{array}{l}\text { Increases the strength of the hair (because of its } \\
\text { great penetration) }\end{array}$ \\
\hline $\begin{array}{l}\text { Seveov (http://www.naturex.asia/uk_l/markets/ } \\
\text { personal-care/natbeautytm/ seveov.html) }\end{array}$ & Natural (maca root extract) & $\begin{array}{l}\text { It protects the hair bulb and shaft. It stimulates } \\
\text { cell division in the hair shaft and bulb }\end{array}$ \\
\hline $\begin{array}{l}\text { Hairomega (http://thehairlossre view.com/hairomega_ } \\
\text { review.html/) }\end{array}$ & $\begin{array}{l}\text { Natural (formulation that contains } \\
\text { [200 mg] saw palmetto and [300 mg] } \\
\beta \text {-sitosterol as the main ingredients) }\end{array}$ & Inhibits $5 \alpha$-reductase and formation of DHT \\
\hline Green tea (Epigallocatechin gallate) ${ }^{43,91}$ & Natural (polyphenol antioxidant) & Inhibits $5 \alpha$-reductase and formation of DHT \\
\hline $\begin{array}{l}\text { Nioxin (formulation of Coenzyme QI0 and } \\
\text { other coenzymes) http://www.nioxin.c om/ } \\
\text { en-US?\&utm_source=google\&utm_mediu } \\
\text { m=cpc\&utm_term=nioxin\&utm_campa } \\
\text { ign=Nioxin_Search_Brand+Awareness \&utm_ } \\
\text { content=sM PLIfxxa|dc_45273I 952I7_e_nioxin\&g } \\
\text { clid=CJSy3JbH0cg CFYI7fgodMTIDK Q }\end{array}$ & Synthetic & Inhibits $5 \alpha$-reductase and formation of DHT \\
\hline Alfatradiol (I $7 \alpha$-estradiol) $)^{44}$ & Synthetic (small molecule) & Inhibits type II $5 \alpha$-reductase \\
\hline Quercetin $^{84}$ & $\begin{array}{l}\text { Natural (flavonoid found in several } \\
\text { non-citrus fruits, vegetables, leaves, } \\
\text { and grains) }\end{array}$ & Inhibits PGD2 \\
\hline
\end{tabular}

Abbreviations: AGA, androgenic alopecia; DHT, dihydrotestosterone; ECM, extracellular matrix; FDA, US Food and Drug Administration; PGD2, prostaglandin D2; PKC, protein kinase $C$; TGF- $\beta$ I, transforming growth factor $\beta$ I.

Some of these factors, such as epidermal growth factor (EGF), basic fibroblast growth factor, hepatocyte growth factor (HGF) and HGF activator, VEGF, insulin-like growth factor (IGF), TGF- $\beta$, and platelet-derived growth factor (PDGF), are able to provide signals that promote hair growth. ${ }^{15,60-64}$ As mentioned before, DPCs provide signals to HFSCs located in the bulge that proliferate and migrate either to the DP or to the epidermis to repopulate the basal layer (Figure 1). ${ }^{32,65}$ Enhancement in growth factor expression (except for EGF) has been reported when the adipose SCs are cultured in hypoxic conditions. ${ }^{15}$ Also, SCs increase their self-renewal capacity under these conditions. ${ }^{66-68}$ Low oxygen concentrations $(1 \%-5 \%)$ increase the level of expression of SC factors that include VEGF, basic fibroblast growth factor, IGF binding protein 1 (IGFBP-1), IGF 
Table 3 Stem cell factors and small molecules that promote hair growth and their mechanisms of action

\begin{tabular}{|c|c|}
\hline Factor & Mechanism of action \\
\hline HGF and HGF activator ${ }^{61}$ & Factor secreted by DPC that promotes proliferation of epithelial follicular cells \\
\hline $\mathrm{EGF}^{60}$ & $\begin{array}{l}\text { Promotes growth and migration of follicle ORS cells by activation of } \mathrm{Wnt} / \beta \text {-catenin } \\
\text { signaling }\end{array}$ \\
\hline bFGF 62 & Promotes the development of hair follicle \\
\hline IL-6 $6^{93}$ & Involved in WIHN through STAT3 activation \\
\hline VEGF 72 & Promotes perifollicular angiogenesis \\
\hline TGF- $\beta^{63}$ & Stimulates the signaling pathways that regulate hair cycle \\
\hline IGF-1 & Promotes proliferation, survival, and migration of hair follicle cells \\
\hline IGFBP-I to $-6^{70}$ & $\begin{array}{l}\text { Regulates IGF-I effects and its interaction with extracellular matrix proteins at the hair } \\
\text { follicle level }\end{array}$ \\
\hline $\mathrm{BMP}^{23}$ & Maintains DPC phenotype which is crucial for stimulation of hair follicle stem cell \\
\hline BMPRIa ${ }^{23}$ & Maintains the proper identity of DPCs that is essential for specific DPC function \\
\hline $\mathrm{M}-\mathrm{CSF}^{71}$ & Involved in wound-induced hair regrowth \\
\hline M-CSFR ${ }^{71}$ & Involved in wound-induced hair regrowth \\
\hline PDGF and PDGFR- $\beta /-\alpha^{64}$ & $\begin{array}{l}\text { Upregulates the genes involved in hair follicle differentiation. Induction and regulation of } \\
\text { anagen phase. PDGF and its receptors are essential for follicular development }\end{array}$ \\
\hline Wnt3a $a^{97}$ & Involved in hair follicle development through $\beta$-catenin signaling \\
\hline PGE2 $^{79,80}$ & Stimulates anagen phase in hair follicles \\
\hline PGF2 $\alpha$ and analogs ${ }^{79,80}$ & Promotes transition from telogen to anagen phase of the hair cycle \\
\hline $\mathrm{BIO} 98$ & GSK-3 inhibitor \\
\hline $\begin{array}{l}\text { PGE2 or inhibition of PGD2 or PGD2 receptor D2/ } \\
\text { GPR44 }\end{array}$ & Promotes follicle regeneration \\
\hline Iron and I-lysine ${ }^{95}$ & Under investigation \\
\hline
\end{tabular}

Abbreviations: bFGF, basic fibroblast growth factor; BIO, (2'Z,3'E)-6-bromoindirubin-3'-oxime; BMP, bone morphogenetic protein; DPCs, dermal papilla cells; EGF, epidermal growth factor; GSK-3, glycogen synthase kinase-3; HGF, hepatocyte growth factor; IGF-I, insulin-like growth factor I; IGFBP-I, insulin-like growth factor-binding protein I; IL-6, interleukin-6; M-CSF, microphage colony-stimulating factor; M-CSFR, microphage colony-stimulating factor receptor; ORS, outer root sheath; PDGF, plateletderived growth factor; PDGFR- $\alpha$, platelet-derived growth factor receptor alpha; PDGFR- $\beta$, platelet-derived growth factor receptor beta; PGD2, prostaglandin D2; PGE2, prostaglandin E2; TGF- $\beta$ I, transforming growth factor $\beta$ I; VEGF, vascular endothelial growth factor; WIHN, wound-induced hair neogenesis; Wnt3a, wingless-type MMTV integration site family, member $3 \mathrm{~A}$.

binding protein 2 (IGFBP-2), macrophage colony-stimulating factor (M-CSF), M-CSF receptor (M-CSFR), and PDGF receptor $\beta$ (PDGFR- $\beta$ ). ${ }^{15,69,70}$ While these groups of factors promote HF growth in intact skin, another group of factors, such as M-CSF, M-CSFR, and interleukin-6, are involved in wound-induced hair neogenesis. ${ }^{71} \mathrm{HGF}$ and HGF activator stimulate DPCs to promote proliferation of epithelial follicular cells. ${ }^{61}$ Epidermal growth factor promotes cellular migration via the activation of $\mathrm{Wnt} / \beta$-catenin signaling. ${ }^{60} \mathrm{VEGF}$ promotes hair growth and increases the follicle size mainly by perifollicular angiogenesis. ${ }^{72}$ Blocking VEGF activity by neutralizing antibodies reduced the size and growth of the $\mathrm{HF}^{72}$ PDGF and its receptor (PDGFR- $\alpha$ ) are essential for follicular development by promoting upregulation of genes involved in HF differentiation and regulating the anagen phase in HFs. ${ }^{64,73}$ They are also expressed in neonatal skin cells that surround the $\mathrm{HF}^{73}$ Monoclonal antibodies to PDGFR- $\alpha$ (APA5) produced failure in hair germ induction, supporting that PDGFR- $\alpha$ and its ligand have an essential role in hair differentiation and development. ${ }^{73}$ IGF-1 promotes proliferation, survival, and migration of HF cells. ${ }^{69,74}$ In addition, IGF binding proteins (IGFBPs) also promote hair growth and hair cell survival by regulating IGF-1 effects and its interaction with extracellular matrix proteins in the HF. ${ }^{70}$ Higher levels of IGF-1 and IGFBPs in beard DPCs suggest that IGF-1 levels are associated with androgens. ${ }^{74}$ Furthermore, DPCs from non-balding scalps showed significantly higher levels of IGF-1 and IGFBP-6, in contrast to DPCs from balding scalps. ${ }^{74}$

\section{Small molecules}

Small molecules with low molecular weight ( $<900 \mathrm{Da})$ and the size of $10^{-9} \mathrm{~m}$ are organic compounds that are able to regulate some biologic processes. ${ }^{75}$ Some small molecules have been tested for their role in hair growth. ${ }^{76}$ Synthetic, non-peptidyl small molecules that act as agonists of the hedgehog pathway have the ability to promote follicular cycling in adult mouse skin. ${ }^{76}$ PGE2 and prostaglandin D2 (PGD2) have also been associated with the hair cycle (Table 3). ${ }^{77}$ PGD2 is elevated in the scalp of balding men and inhibits hair lengthening via GPR44 receptor. ${ }^{78}$ Also, it is known that PGE2 and PGF2 $\alpha$ promote hair growth, while PGD2 inhibits this process. ${ }^{77,79}$ Prostaglandin analogs of PGF2 $\alpha$ have been used originally to decrease ocular pressure in glaucoma with parallel effects in the growth of eyelashes, which suggests a 
specific effect in HF activation. ${ }^{80} \mathrm{PGD} 2$ receptors are located in the upper and lower ORS region and in the DP, suggesting that these prostaglandins play an important role in hair cycle. ${ }^{81}$ Molecules such as quercetin are able to inhibit PGD2 and, in this way, promote hair growth. ${ }^{82-84}$ Antagonists of PGD2 receptor (formally named chemoattractant receptorhomologous expressed in Th2 cells) such as setipiprant have been used to treat allergic diseases such as asthma, but they also have beneficial effects in AGA ${ }^{85-87}$ Another small molecule 1-ascorbic acid 2-phosphate promotes proliferation of ORS keratinocytes through the secretion of IGF-1 from DPCs via phosphatidylinositol 3-kinase. ${ }^{88}$ Recently, it has been described that small-molecule inhibitors of Janus kinase-signal transducer and activator of transcription (JAK-STAT) pathway promote hair regrowth in humans. ${ }^{89}$ Janus kinase inhibitors are currently approved by the FDA for the treatment of some specific diseases such as psoriasis and other autoimmune-mediated diseases. ${ }^{90-94}$ Also, another group of small molecules such as iron and the amino acid 1-Lysine are essential for hair growth (Table 3). ${ }^{95}$

\section{Cellular therapy}

The multipotent SCs in the bulge region of the HF receive signals from DPCs in order to proliferate and survive. ${ }^{27,28,65,84,96} \mathrm{It}$ has been shown that $\mathrm{Wnt} / \beta$-catenin signaling is essential for the growth and maintenance of DPCs. ${ }^{19,97}$ These cells can be isolated and cultured in vitro with media supplemented with $10 \%$ fetal bovine serum and FGF-2. ${ }^{37,98}$ However, they lose versican expression that correlates with decrease in follicleinducing activity in culture. ${ }^{98}$ Versican is the most abundant component of HF extracellular matrix. ${ }^{99}$ Inhibition of glycogen synthase kinase-3 by $\left(2^{\prime} Z, 3^{\prime} \mathrm{E}\right)$-6-bromoindirubin-3'oxime (BIO) promotes hair growth in mouse vibrissa follicles in culture by activation of Wnt signaling. ${ }^{98}$ Therefore, the increase of Wnt signaling in DPCs apparently is one of the main factors that promote hair growth. ${ }^{19}$ DPCs have been also generated from human embryonic SCs that induced HF formation after murine transplantation. ${ }^{27}$

\section{Platelet-rich plasma}

Platelets are anucleate cells generated by fragmentation of megakaryocytes in the bone marrow. ${ }^{100}$ These cells are actively involved in the hemostatic process after releasing biologically active molecules (cytokines). ${ }^{100-102}$ Because of the platelets' higher capacity to produce and release these factors, autologous platelet-rich plasma (PRP) has been used to treat chronic wounds. ${ }^{103}$ Therefore, PRP can be used as autologous therapy for regenerative purposes, for example, chondrogenic differentiation, wound healing, fat grafting, AGA, alopecia areata, facial scars, and dermal volume augmentation. ${ }^{101,104-108}$ PRP contains human platelets in a small volume that is five to seven times higher than in normal blood and it has been proven to be beneficial to treat AGA. ${ }^{10,105,109-111}$ The factors released by these platelets after their activation, such as PDGFs (PDGFaa, PDGFbb, PDGFab), TGF- $\beta 1$, TGF- $\beta 2$, EGF, VEGF, and FGF, promote proliferation of DPCs and, therefore, may be beneficial for AGA treatment. ${ }^{109,112-114}$ Clinical experiments indicate that patients with AGA treated with autologous PRP show improved hair count and thickness. ${ }^{109}$

\section{In search of novel therapies}

In this paper, we reviewed and discussed the use of therapeutic agents for hair regeneration and the knowledge to promote the development of new therapies for AGA based on the advances in regenerative medicine. The HF is a complex structure that grows when adequate signaling is provided to the HFSCs. These cells are located in the follicle bulge and receive signals from MSCs located in the dermis that are called DPCs. The secretory phenotype of DPCs is determined by local and circulatory signals or hormones. Recent discoveries have demonstrated that SCs in culture are able to activate DPCs and HFSCs and, in this way, promote hair growth. The study of these cellular signals can provide the necessary knowledge for developing more effective therapeutic agents for the treatment of AGA with minimal side effects. Therefore, advancements in the field of regenerative medicine may generate novel therapeutic alternatives. However, further research and clinical studies are needed to evaluate their efficacy.

\section{Disclosure}

The authors report no conflicts of interest in this work.

\section{References}

1. Blumeyer A, Tosti A, Messenger A, et al; European Dermatology Forum (EDF). Evidence-based (S3) guideline for the treatment of androgenetic alopecia in women and in men. J Dtsch Dermatol Ges. 2011;9(Suppl 6):S1-S57.

2. Ramos PM, Miot HA. Female pattern hair loss : a clinical and pathophysiological review. An Bras Dermatol. 2015;90(4):529-543.

3. Otberg N, Finner AM, Shapiro J. Androgenetic alopecia. Endocrinolo Metab Clin North Am. 2007;36(2):379-398.

4. Plikus MV, Chuong CM. Complex hair cycle domain patterns and regenerative hair waves in living rodents. $J$ Invest Dermatol. 2008;128(5):1071-1080.

5. McElwee KJ, Shapiro JS. Promising therapies for treating and/or preventing androgenic alopecia. Skin Therapy Lett. 2012;17(6):1-4.

6. Perez-Mora N, Velasco C, Bermüdez F. Oral finasteride presents with sexual-unrelated withdrawal in long-term treated androgenic alopecia in men. Skinmed. 2015;13(3):179-183. 
7. Gupta AK, Charrette A. Topical minoxidil: systematic review and meta-analysis of its efficacy in androgenetic alopecia. Skinmed. 2015;13(3):185-189.

8. Shapiro J, Kaufman KD. Use of finasteride in the treatment of men with androgenetic alopecia (male pattern hair loss). J Investig Dermatol Symp Proc. 2003;8(1):20-23.

9. Rossi A, Anzalone A, Fortuna MC, et al. Multi-therapies in androgenetic alopecia: review and clinical experiences. Dermatol Ther. 2016;29(6):424-432.

10. Varothai S, Bergfeld WF. Androgenetic alopecia: an evidence-based treatment update. Am J Clin Dermatol. 2014;15(3):217-230.

11. Rossi A, Cantisani C, Melis L, Iorio A, Scali E, Calvieri S. Minoxidil use in dermatology, side effects and recent patents. Recent Pat Inflamm Allergy Drug Discov. 2012;6(2):130-136.

12. Motofei IG, Rowland DL, Georgescu SR, Mircea T, Baleanu BC, Paunica $\mathrm{S}$. Are hand preference and sexual orientation possible predicting factors for finasteride adverse effects in male androgenic alopecia? Exp Dermatol. 2016;25(7):557-558.

13. Reijo Pera RA, Gleeson JG. Stems cells and regeneration: special review issue. Hum Mol Gen. 2008;17(R1):R1-R2.

14. Jain R, De-Eknamkul W. Potential targets in the discovery of new hair growth promoters for androgenic alopecia. Expert Opin Ther Targets. 2014;18(7):787-806.

15. Park BS, Kim WS, Choi JS, et al. Hair growth stimulated by conditioned medium of adipose-derived stem cells is enhanced by hypoxia : evidence of increased growth factor secretion. Biomed Res. 2010;31(1):27-34.

16. Fukuoka $H$, Suga $H$. Hair regeneration treatment using adipose-derived stem cell conditioned medium :follow-up with trichograms. Eplasty. 2015;15:65-72.

17. Du Y, Roh DS, Funderburgh ML, et al. Adipose-derived stem cells differentiate to keratocytes in vitro. Mol Vis. 2010;16:2680-2689.

18. Zhang P, Kling RE, Ravuri SK, et al. A review of adipocyte lineage cells and dermal papilla cells in hair follicle regeneration. J Tissue Eng. 2014;5:2041731414556850.

19. Tsai SY, Sennett R, Rezza A, et al. Wnt/ $\beta$-catenin signaling in dermal condensates is required for hair follicle formation. Dev Biol. 2014;385(2):179-188.

20. Choi YS, Zhang Y, Xu M, et al. Distinct functions for Wnt/ $\beta$-catenin in hair follicle stem cell proliferation and survival and interfollicular epidermal homeostasis. Cell Stem Cell. 2013;13(6):720-733.

21. Rao TP, Kuhl M. An updated overview on Wnt signaling pathways a prelude for more. Circ Res. 2010;106(12):1798-1806.

22. Yano K, Brown LF, Detmar M. Control of hair growth and follicle size by VEGF-mediated angiogenesis. J Clin Invest. 2001;107(4):409-417.

23. Rendl M, Polak L, Fuchs E. BMP signaling in dermal papilla cells is required for their hair follicle-inductive properties. Genes Dev. 2008;22(4):543-557.

24. Talavera-Adame D, Gupta A, Kurtovic S, Chaiboonma KL, Arumugaswami V, Dafoe DC. Bone morphogenetic protein-2/-4 upregulation promoted by endothelial cells in coculture enhances mouse embryoid body differentiation. Stem Cells Dev. 2013;22(24):3252-3260.

25. Talavera-Adame D, Wu G, He Y, et al. Endothelial Cells in Co-culture Enhance Embryonic Stem Cell Differentiation to Pancreatic Progenitors and Insulin-Producing Cells through BMP Signaling. Stem Cell Rev. 2011;7(3):532-543.

26. Talavera-Adame D, Ng TT, Gupta A, Kurtovic S, Wu GD, Dafoe DC. Characterization of microvascular endothelial cells isolated from the dermis of adult mouse tails. Microvascular Res. 2011;82(2):97-104.

27. Gnedeva K, Vorotelyak E, Cimadamore F, et al. Derivation of hair-inducing cell from human pluripotent stem cells. PLoS One. 2015;10(1):1-14.

28. Lavker RM, Sun T, Oshima H, et al. Hair follicle stem cells. J Investig Dermatol Symp Proc. 2003;8(1):28-38.

29. Bernard B. Advances in understanding hair growth. F1000Res. 2016;5:1-8
30. Lay K, Kume T, Fuchs E. FOXC1 maintains the hair follicle stem cell niche and governs stem cell quiescence to preserve long-term tissue-regenerating potential. Proc Natl Acad Sci U SA. 2016;113(1): E1506-E1515.

31. Leirós GJ, Attorresi AI, Balañá ME. Hair follicle stem cell differentiation is inhibited through cross-talk between Wnt/ $\beta$-catenin and androgen signalling in dermal papilla cells from patients with androgenetic alopecia. Br J Dermatol. 2012;166(5):1035-1042.

32. Chacon-Martinez CA, Klose M, Niemann C, Glauche I, Wickström SA. Hair follicle stem cells $=$ cultures reveal self-organizing plasticity of stem cells and their progeny. EMBO J. 2017;36(2):151-164.

33. Soler AP, Gilliard G, Megosh LC, O’Brien TG. Modulation of murine hair follicle function by alterations in ornithine decarboxylase activity. J Invest Dermatol. 1996;106(5):1108-1113.

34. Hsu YC, Pasolli HA, Fuchs E. Dynamics between stem cells, nich and progeny in the hair follicle. Cell. 2011;144(1):92-105.

35. Kang JI, Kim SC, Kim MK, et al. Effects of dihydrotestosterone on rat dermal papilla cells in vitro. Eur J Pharmacol. 2015;757:74-83.

36. Yamana K, Labrie F, Luu-The V. Human type $35 \alpha$-reductase is expressed in peripheral tissues at higher levels than types 1 and 2 and its activity is potently inhibited by finasteride and dutasteride. Horm Mol Biol Clin Investig. 2010;2(3):293-299.

37. Osada A, Iwabuchi T, Kishimoto J, Hamazaki TS, Okochi H. Longterm culture of mouse vibrissal dermal papilla cells and de novo hair follicle induction. Tissue Eng. 2007;13(5):975-982.

38. Choi GS, Kim JH, Oh SY, et al. Safety and tolerability of the dual 5-alpha reductase inhibitor dutasteride in the treatment of androgenetic alopecia. Ann Dermatol. 2016;28(4):444-450.

39. Carson $\mathrm{C}$ 3rd, Rittmaster $\mathrm{R}$. The role of dihydrotestosterone in benign prostatic hyperplasia. Urology. 2003;61(4 Suppl 1):2-7.

40. Kamimura A, Takahashi T. Procyanidin B-2, extracted from apples, promotes hair growth: a laboratory study. Br J Dermatol. 2002;146(1): 41-51.

41. Kamimura A, Takahashi T. Procyanidin B-3, isolated from barley and identified as a hair-growth stimulant, has the potential to counteract inhibitory regulation by TGF-beta1. Exp Dermatol. 2002;11(6):532-541.

42. Ulbricht C, Basch E, Bent S, et al. Evidence-based systematic review of saw palmetto by the Natural Standard Research Collaboration. $J$ Soc Integr Oncol. 2006;4(4):170-186.

43. Rondanelli M, Perna S, Peroni G, Guido D. A bibliometric study of scientific literature in Scopus on botanicals for treatment of androgenetic alopecia. J Cosmet Dermatol. 2015;15(2):120-130.

44. Blume-Peytavi U, Kunte C, Krisp A, Garcia Bartels N, Ellwanger U, Hoffmann R. [Comparison of the efficacy and safety of topical minoxidil and topical alfatradiol in the treatment of androgenetic alopecia in women.] J Dtsch Dermatol Ges. 2007;5(5):391-395. German.

45. Farivar S, Malekshahabi T, Shiari R. Biological effects of low level laser therapy. J Lasers Med Sci. 2014;5(2):58-62.

46. Maiman TH. Biomedical lasers evolve toward clinical applications. Hosp Manage. 1966;101(4):39-41.

47. Cung H, Dai T, Sharma SK, et al. The nuts and bolts of low-level laser (light) therapy. Ann Biomed Eng. 2013;40(2):516-533.

48. Bjordal JM, Couppé C, Chow RT, Tunér J, Ljunggren EA. A systematic review of low level laser therapy with location-specific doses for pain from chronic joint disorders. The Aust J Physiother. 2003;49(2):107-116.

49. Brosseau L, Welch V, Wells G, et al. Low level laser therapy (classes I, II and III) in the treatment of rheumatoid arthritis. Cochrane Database Syst Rev. 2005;19(2):CD002049.

50. Cauwels RGEC, Martens LC. Low level laser therapy in oral mucositis: a pilot study. Eur Arch Paediatr Dent. 2011;12(2):118-123.

51. Schindl A, Schindl M, Pernerstorfer-Schön H, Schindl L. Low-intensity laser therapy: a review. J Investig Med. 2000;48(5):312-326.

52. Liu H, Colavitti R, Rovira II, Finkel T. Redox-dependent transcriptional regulation. Cir Res. 2005;97(10):967-974. 
53. Gupta AK, Lyons DCA, Abramovits W. Low-level laser/light therapy for androgenetic alopecia. Skinmed. 2014;12(3):145-147.

54. Jimenez JJ, Wikramanayake TC, Bergfeld W, et al. Efficacy and safety of a low-level laser device in the treatment of male and female pattern hair loss: a multicenter, randomized, sham device-controlled, doubleblind study. Am J Clin Dermat. 2014;15(2):115-127.

55. Chen $\mathrm{CH}$, Hung HS, Hsu SH. Low-energy laser irradiation increases endothelial cell proliferation, migration, and eNOS gene expression possibly via PI3K signal pathway. Lasers Surg Med. 2008;40(1):46-54.

56. Tuby H, Maltz L, Oron U. Modulations of VEGF and iNOS in the rat heart by low level laser therapy are associated with cardioprotection and enhanced angiogenesis. Lasers Surg Med. 2006;38(7):682-688.

57. Avci P, Gupta GK, Clark J, Wikonkal N, Hamblin MR. Low-level laser (light) therapy (LLLT) for treatment of hair loss. Laser Surg Med. 2015;46(2):144-151.

58. Rodrigues C, de Assis AM, Moura DJ, et al. New therapy of skin repair combining adipose-derived mesenchymal stem cells with sodium carboxymethylcellulose scaffold in a pre-clinical rat model. PloS One. 2014;9(5):e96241.

59. Gimble JM, Katz AJ, Bunnell BA. Adipose-derived stem cells for regenerative medicine. Cir Res. 2007;100(9):1249-1260.

60. Zhang H, Nan W, Wang S, et al. Epidermal growth factor promotes proliferation and migration of follicular outer root sheath cells via Wnt/ $\beta$-catenin signaling. Cell Physiol Biochem. 2016;39(1): $360-370$

61. Lee YR, Yamazaki M, Mitsui S, Tsuboi R, Ogawa H. Hepatocyte growth factor (HGF) activator expressed in hair follicles is involved in in vitro HGF-dependent hair follicle elongation. J Dermatol Sci. 2001;25(2):156-163.

62. du Cros DL. Fibroblast growth factor influences the development and cycling of murine hair follicles. Dev Biol. 1993;156(2):444-453.

63. Niimori D, Kawano R, Felemban A, et al. Tsukushi controls the hair cycle by regulating TGF- $\beta 1$ signaling. Dev Biol. 2012;372(1):81-87.

64. Tomita Y, Akiyama M, Shimizu H. PDGF isoforms induce and maintain anagen phase of murine hair follicles. J Dermatol Sci. 2006;43(2): $105-115$.

65. Ohyama M, Terunuma A, Tock CL, et al. Characterization and isolation of stem cell - enriched human hair follicle bulge cells. J Clin Invest. 2006;116(1):249-260.

66. Grayson WL, Zhao F, Bunnell B, Ma T. Hypoxia enhances proliferation and tissue formation of human mesenchymal stem cells. Biochem Biophys Res Commun. 2007;358(3):948-953.

67. Potier E, Ferreira E, Andriamanalijaona R, et al. Hypoxia affects mesenchymal stromal cell osteogenic differentiation and angiogenic factor expression. Bone. 2007;40(4):1078-1087.

68. Ren H, Cao Y, Zhao Q, et al. Proliferation and differentiation of bone marrow stromal cells under hypoxic conditions. Biochem Biophys Res Commun. 2006;347(1):12-21.

69. Su HY, Hickford JG, Bickerstaffe R, Palmer BR. Insulin-like growth factor 1 and hair growth. Dermatol Online J. 1999;5(2):1.

70. Batch JA, Mercuri FA, Werther GA. Identification and localization of insulin-like growth factor-binding protein (IGFBP) messenger RNAs in human hair follicle dermal papilla. $J$ Invest Dermatol. 1996;106(3):471-475.

71. Osaka N, Takahashi T, Murakami S, et al. ASK1-dependent recruitment and activation of macrophages induce hair growth in skin wounds. J Cell Biol. 2007;176(7):903-909.

72. Yano K, Brown LF, Detmar M. Control of hair growth and follicle size by VEGF-mediated angiogenesis. J Clin Invest. 2001;107(4):409-417.

73. Takakura N, Yoshida H, Kunisada T, Nishikawa S, Nishikawa SI. Involvement of platelet-derived growth factor receptor- $\alpha$ in hair canal formation. J Invest Dermatol. 1996;107(5):770-777.

74. Panchaprateep R, Asawanonda P. Insulin-like growth factor-1: roles in androgenetic alopecia. Exp Dermatol. 2014;23(3):216-218.

75. Castoreno AB, Eggert US. Small molecule probes of cellular pathways and networks. ACS Chem Biol. 2011;6(1):86-94.
76. Paladini RD, Saleh J, Qian C, Xu GX, Rubin LL. Modulation of hair growth with small molecule agonists of the hedgehog signaling pathway. J Iinvest Dermatol. 2005;125(4):638-646.

77. Nieves A, Garza LA. Does prostaglandin D2 hold the cure to male pattern baldness? Exp Dematol. 2014;(29):224-227.

78. Nelson AM, Loy DE, Lawson JA, Katseff AS, Fitzgerald GA, Garza LA. Prostaglandin D2 inhibits wound-induced hair follicle neogenesis through the receptor Gpr44. J Invest Dermatol. 2013;133(4):881-889.

79. Sasaki S, Hozumi Y, Kondo S. Influence of prostaglandin F2alpha and its analogues on hair regrowth and follicular melanogenesis in a murine model. Exp Dermatol. 2005;14(5):323-328.

80. Choi YM, Diehl J, Levins PC. Promising alternative clinical uses of prostaglandin F2 $\alpha$ analogs: beyond the eyelashes. JAm Acad Dermatol. 2015;72(4):712-716.

81. Colombe L, Michelet JF, Bernard BA. Prostanoid receptors in anagen human hair follicles. Exp Dermatol. 2008;17(1):63-72.

82. Zhang Q, Major MB, Takanashi S, et al. Small-molecule synergist of the Wnt/beta-catenin signaling pathway. Proc Natl Acad Sci U S A. 2007;104(18):7444-7448.

83. Fong P, Tong HH, Ng KH, Lao CK, Chong CI, Chao CM. In silicoprediction of prostaglandin D2 synthase inhibitors from herbal constituents for the treatment of hair loss. J Ethnopharmacol. 2015; 175:470-480.

84. Weng Z, Zhang B, Asadi S, et al. Quercetin is more effective than cromolyn in blocking human mast cell cytokine release and inhibits contact dermatitis and photosensitivity in humans. PloS One. 2012;7(3):e33805.

85. Norman P. Update on the status of DP2 receptor antagonists; from proof of concept through clinical failures to promising new drugs. Expert Opin Investig Drugs. 2014;23(1):55-66.

86. Pettipher R. The roles of the prostaglandin D(2) receptors DP(1) and CRTH2 in promoting allergic responses. Br J Pharmacol. 2008;153(Suppl 1):S191-S199.

87. Garza LA, Liu Y, Yang Z, et al. Prostaglandin D2 inhibits hair growth and is elevated in bald scalp of men with androgenetic alopecia. $S c i$ Transl Med. 2012;4(126):126ra34.

88. Kwack MH, Shin SH, Kim SR, et al. I-Ascorbic acid 2-phosphate promotes elongation of hair shafts via the secretion of insulin-like growth factor-1 from dermal papilla cells through phosphatidylinositol 3-kinase. Br J Dermatol. 2009;160(6):1157-1162.

89. Harel S, Higgins CA, Cerise JE, et al. Pharmacologic inhibition of JAKSTAT signaling promotes hair growth. Sci Adv. 2015;1(9):e1500973.

90. Quintás-cardama A, Vaddi K, Liu P, et al. INCB018424 : therapeutic implications for the treatment of myeloproliferative neoplasms Preclinical characterization of the selective JAK1 / 2 inhibitor INCB018424 : therapeutic implications for the treatment of myeloproliferative neoplasms. Blood. 2014;115(15):3109-3117.

91. Geyer HL, Mesa RA. Therapy for myeloproliferative neoplasms: when, which agent, and how? Hematology Am Soc Hematol Educ Program. 2014;2014(1):277-286.

92. Ghoreschi K, Jesson MI, Li X, et al. Modulation of innate and adaptive immune responses by tofacitinib (CP-690,550). J Immunol. 2012;186(7):4234-4243.

93. Kontzias A, Laurence A, Gadina M, O'Shea JJ. Kinase inhibitors in the treatment of immune-mediated disease. F1000 Med Rep. 2012;4:5.

94. Bao L, Zhang H, Chan LS. The involvement of the JAK-STAT signaling pathway in chronic inflammatory skin disease atopic dermatitis. JAKSTAT. 2013;2(3):1-8.

95. Rushton DH. Nutritional factors and hair loss. Clin Exp Dermatol. 2002;27(5):396-404.

96. Oshima H, Rochat A, Kedzia C, Kobayashi K, Barrandon Y. Morphogenesis and renewal of hair follicles from adult multipotent stem cells. Cell. 2001;104(2):233-245.

97. Huelsken J, Vogel R, Erdmann B, Cotsarelis G, Birchmeier W. betaCatenin controls hair follicle morphogenesis and stem cell differentiation in the skin. Cell. 2001;105(4):533-545. 
98. Yamauchi K, Kurosaka A. Inhibition of glycogen synthase kinase-3 enhances the expression of alkaline phosphatase and insulin-like growth factor-1 in human primary dermal papilla cell culture and maintains mouse hair bulbs in organ culture. Arch Dermatol Res. 2009;301(5): 357-365.

99. Sotoodehnejadnematalahi F, Burke B. Structure, function and regulation of versican: the most abundant type of proteoglycan in the extracellular matrix. Acta Med Iran. 2013;51(11):740-750.

100. Xu XR, Zhang D, Oswald BE, et al. Platelets are versatile cells: new discoveries in hemostasis, thrombosis, immune responses, tumor metastasis and beyond. Crit Rev Clin Lab Sci. 2016;53(6):409-430.

101. Lacci KM, Dardik A. Platelet-rich plasma: support for its use in wound healing. Yale J Biol Med. 2010;83(1):1-9.

102. Mussano F, Genova T, Munaron L, Petrillo S, Erovigni F, Carossa S. Cytokine, chemokine, and growth factor profile of platelet-rich plasma. Platelets. 2016;27(5):467-471.

103. Martinez-Zapata MJ, Martí-Carvajal AJ, Solà I, et al. Autologous platelet-rich plasma for treating chronic wounds. Cochrane Database Syst Rev. 2016;(5):CD006899.

104. Modarressi A. Platlet Rich Plasma (PRP) improves fat grafting outcomes. World J Plast Surg. 2013;2(1):6-13.

105. Gentile P, Garcovich S, Bielli A, Scioli MG, Orlandi A, Cervelli V. The Effect of platelet-rich plasma in hair regrowth: a randomized placebocontrolled trial. Stem Cells Transl Med. 2015;4(11):1317-1323.

106. Lynch MD, Bashir S. Applications of platelet-rich plasma in dermatology: a critical appraisal of the literature. J Dermatolog Treat. 2016;27(3):285-289.
107. Trink A, Sorbellini E, Bezzola P, et al. A randomized, double-blind, placebo- and active-controlled, half-head study to evaluate the effects of platelet-rich plasma on alopecia areata. $\mathrm{Br} \mathrm{J}$ Dermatol. 2013;169(3):690-694.

108. Oh Y, Kim BJ, Kim MN. Depressed facial scars successfully treated with autologous platelet-rich plasma and light-emitting diode phototherapy at $830 \mathrm{~nm}$. Ann Dermatol. 2014;26(3):417-418.

109. Singhal P,Agarwal S, Dhot PS, Sayal SK. Efficacy of platelet-rich plasma in treatment of androgenic alopecia. Asian J Transfus Sci. 2015;9(2): 159-162.

110. Valente Duarte de Sousa IC, Tosti A. New investigational drugs for androgenetic alopecia. Expert Opin Investig Drugs. 2013;22(5): 573-589.

111. Alves R, Grimalt R. Randomized placebo-controlled, double-blind, half-head study to assess the efficacy of platelet-rich plasma on the treatment of androgenetic alopecia. Dermatol Surg. 2016;42(4): 491-497.

112. Cho JW, Kim SA, Lee KS. Platelet-rich plasma induces increased expression of G1 cell cycle regulators, type I collagen, and matrix metalloproteinase-1 in human skin fibroblasts. Int $J$ Mol Med. 2012;29(1):32-36.

113. Mehta V. Platelet-rich plasma: a review of the science and possible clinical applications. Orthopedics. 2010;33(2):111.

114. Leo MS, Kumar AS, Kirit R, Konathan R, Sivamani RK. Systematic review of the use of platelet-rich plasma in aesthetic dermatology. $J$ Cosmet Dermatol. 2015;14(4):315-323.
Stem Cells and Cloning: Advances and Applications

\section{Publish your work in this journal}

Stem Cells and Cloning: Advances and Applications is an international peer-reviewed, open access journal. Areas of interest in stem cell research include: Embryonic cell stems; Adult stem cells; Blastocysts; Cordblood stem cells; Stem cell transformation and culture; Therapeutic cloning; Umbilical cord blood and bone marrow cells; Laboratory,

\section{Dovepress}

animal and human therapeutic studies; Philosophical and ethical issues related to stem cell research. This journal is indexed on CAS. The manuscript management system is completely online and includes a quick and fair peer-review system. Visit http://www.dovepress.com/ testimonials.php to read real quotes from published authors.. 